JABBARI, M.; FAKHERI, B. A.; AGHNOUM, R.; NEZHAD, N. M.; ATAEI, R.; KOOCHAKPOUR, Z. Association mapping of morphological and physiological traits of flag leaf related to drought tolerance in barley. Revista de Agricultura Neotropical, Cassilândia-MS, v. 6, n. 2, p. 7-18, abr./jun. 2019. ISSN 2358-6303.

\title{
Association mapping of morphological and physiological traits of flag leaf related to drought tolerance in barley
}

\author{
Mitra Jabbari ${ }^{1}$, Barat Ali Fakheri ${ }^{2}$, Reza Aghnoum ${ }^{3}$, Nafiseh Mahdi Nezhad ${ }^{2}$, Reza Ataei ${ }^{4}$, \\ Zahra Koochakpour ${ }^{2}$
}

${ }^{1}$ Faculty of Agriculture, Higher Educational Complex of Saravan, Saravan, Sistan and Baluchestan, Iran.

E-mail: Jabbari.mitra2@gmail.com

${ }^{2}$ Department of Plant Breeding and Biotechnology, Faculty of Agriculture, University of Zabol, Zabol, Sistan and Baluchestan, Iran. E-mail: Ba_fakheri@yahoo.com,nmahdinezhad52@gmail.com, z.kouchack@gmail.com

${ }^{3}$ Seed and Plant Improvement Research Department, Khorasan Razavi Agricultural and Natural Resources Research and Education Center, AREEO, Mashhad, Khorasan Razavi, Iran. E-mail: reza.aghnoum@gmail.com

${ }^{4}$ Seed and Plant Improvement Institute, Agricultural Research, Education and Extension Organization (AREEO), Karaj, Alborz, Iran. E-mail: rezaataei63@gmail.com

Received: 22/01/2019; Accepted: 12/02/2019.

\section{ABSTRACT}

Association mapping (AM) has proven to be a powerful approach for dissecting the genetic basis of complex traits. In this study, Quantitative Trait Loci (QTLs) controlling flag leaf characteristics under drought stress were detected in a set of 148 modern spring barley cultivars using AM analysis. Flag leaf length (FLL), flag leaf width (FLW), relative water content (RWC), chlorophyll content, and maximum quantum efficiency of PSII (Fv/Fm) which are important in photosynthetic rate, were evaluated under normal irrigation and drought stress conditions at grain filling stage. Population structure was estimated using Structure $_{2.3}$ and linkage disequilibrium (LD) was estimated by the 'Full Matrix LD' using Tassel $1_{5.0}$. Significant marker/trait associations were investigated based on K-Q matrix using Tassel ${ }_{3.0}$. The analysis of population structure divided the cultivars into two sub-groups. Significant $L D$ values $(P<0.01)$ between polymorphic sites with regions of high and low $L D$ were observed. A total of 84 significant putative genomic regions were identified, which delineated into 37 QTLs under two water treatments. Two stable QTLs on $2 \mathrm{H}$ and $3 \mathrm{H}$ were detected for FLL in drought stress treatment. A QTL for FLL were detected on $2 \mathrm{H}$ in normal treatment, which alone explained around $11 \%$ of phenotypic variance of FLL. This QTL was also associated with the expression of FLW and explained around $7.5 \%$ of phenotypic variance. The results suggest that major loci are located on chromosomes $2 \mathrm{H}, 3 \mathrm{H}, 4 \mathrm{H}$ and $5 \mathrm{H}$ involved in the development of flag leaf characteristics and could be used as selection criteria in barley breeding for drought tolerance.

Keywords: Traits, Genome-Wide Association Mapping, Photosynthetic Capacity, Qtls.

\section{Mapeamento da associação de características morfológicas e fisiológicas da folha índice relacionadas à tolerância à seca em cevada}

\section{RESUMO}

O mapeamento associativo (AM) provou ser uma abordagem adequada para avaliar a base genética de características complexas. Neste estudo, os locos de características quantitativas (QTLs) que controlam as características das folhas índices sob estresse hídrico foram detectados num conjunto de 148 cultivares modernas de cevada, usando a análise de AM. Foram avaliados em condições de irrigação normal e estresse hídrico, na fase de enchimento de grãos, o comprimento da folha índice (FLL), a largura da folha índice (FLW), o teor relativo de água (RWC), o teor de clorofila e a eficiência quântica máxima de PSII ( $\mathrm{Fv} / \mathrm{Fm})$, os quais são importantes na taxa fotossintética. A estrutura populacional foi estimada usando Structure $_{2.3}$ e o desequilíbrio de ligação (LD) foi estimado pela 'Full Matrix LD' usando Tassel ${ }_{5.0}$. Associações significativas de marcadores/traços foram investigadas com base na matriz K-Q usando Tassel ${ }_{3.0}$. A análise da estrutura populacional dividiu os cultivares em dois subgrupos. Foram observados valores significativos de $\mathrm{LD}(\mathrm{P}<0,01)$ entre locais polimórficos com regiões de LD alto e baixo. Um total de 84 regiões genômicas significativas foram identificadas, as quais foram delineadas em 37 QTLs sob duas condições hídricas. Dois QTLs estáveis em $2 \mathrm{H}$ e $3 \mathrm{H}$ foram detectados para o FLL no tratamento de estresse hídrico. Um QTL para FLL foi detectado em $2 \mathrm{H}$ em tratamento normal, o que por si só explicou cerca de $11 \%$ da variância fenotípica da FLL. Esse QTL também foi associado à expressão de FLW e explicou cerca de $7,5 \%$ da variância fenotípica. Os resultados sugerem que os principais locos estão localizados nos cromossomos $2 \mathrm{H}, 3 \mathrm{H}, 4 \mathrm{H}$ e $5 \mathrm{H}$ envolvidos no desenvolvimento das características da folha índice e podem ser usados como critérios de seleção no melhoramento de cevada para tolerância à seca.

Palavras-chave: Traços, Mapeamento da Associação do Genoma Geral, Capacidade Fotossintética, Qtls. 


\section{Introduction}

Drought is considered as a major abiotic factor, which affects productivity in rainfed and upland ecosystems, worldwide. Drought tolerance is a complex trait affected by environmental factors and controlled by many genes with small effects (Fan et al., 2015; Mir et al., 2012; Bimpong et al., 2011). Progress towards breeding drought tolerant crops has been slow because of polygenic inheritance, low heritability traits, and high $\mathrm{G} \times \mathrm{E}$ interactions. Plant response to drought stress involves numerous changes at the physiological, cellular, and molecular levels and is one of the most complex biological processes.

Among cereals, barley (Hordeum vulgare L.) is the fourth important crop in the world (Horsley et al., 2009; Lakew et al., 2013). In cereals, grain yield is an important trait controlled by complex biochemical processes depending on physiological and morphological traits (Berdahl et al., 1972; Mir et al., 2012; Lakew et al., 2013). One of the most important aims of plant breeders is high yielding of cereals, especially barley. The yield production depends on the amount of light received by the photosynthetic units. The organs responsible for light interception are the top three leaves on a stem predominantly. The dimension, position and angle of the leaf (Tungland et al., 1987), which form part of the canopy architecture determine the amount of light intercepted. Flag leaf is well positioned to intercept light. Up to $70 \%$ of the carbohydrates stored in the grains are synthesized by flag leaf (Yap and Harvey, 1972). Increase in grain yield depends on morphological and physiological traits of flag leaf, which has widely been studied previously (Yin et al., 1999; Diab et al., 2004; Gyenis et al., 2007; Wójcik-Jagła et al., 2013).

In drought stress, water use efficiency must be increased to sustain normal growth (Zhao et al., 2010). In crops, relative water content (RWC) is used to measure water status and determines the leaf metabolic activity. The positive relationship of RWC and flag leaf area index with grain yield has been studied previously (Matin et al., 1989; González et al., 2008). Because of intricate measurement procedure and imbalance process of physiological and morphological traits in the developmental stage of barley, using molecular markers is one of the most suitable methods to identify genomic regions involved in drought tolerance (Jannink and Walsh, 2002). Recently, to identify marker/trait associations cultivars, lines, or landraces is used in barley and other plants (Igartua et al., 1999; Thornsberry et al., 2001; Somers et al., 2003; Kraakman et al., 2004; Kraakman et al., 2006; Breseghello and Sorrells, 2006; Agrama et al., 2007; Oraguzie and Wilcox, 2007; Zhu et al., 2008; Hasan et al., 2008).
To understand the adaptation of plants to variety of stresses, genetic variation and mechanisms under stress conditions should be studied (Brachi et al., 2015; Kerwin et al., 2015).

Screening drought tolerance in arid regions should be considered with several agronomical and physiological traits. A few studies have been published to identify markers associated with flag leaf traits involved in drought stress (Lakew et al., 2013; Comadran et al., 2009, 2011). The main objective of the present study was to elucidate the genetic basis of morphological and physiological traits of flag leaf in a collection of spring barley under drought stress using AM analysis.

\section{Material and Methods \\ 2.1. Plant material and field trial}

A total of 148 barley cultivars, which are commercial cultivars in Western European countries (Kraakman et al., 2004) were evaluated under drought stress treatment. The experiment was conducted at Zahak Agricultural Research Station, Sistan and Baluchistan, Iran with geographical characteristics as: Latitude $=30^{\circ} 15^{\prime} \mathrm{N}$ and Longitude $=60^{\circ} 15^{\prime} \mathrm{E}$ and Altitude $=480 \mathrm{~m}$

Genotypes were evaluated in alpha-lattice design with two replications in two conditions: a: irrigation at $90 \%$ FC (normal irrigation) and b: irrigation at $40 \%$ FC (drought stress) during years 2015-2016 and 2016-2017. The measurement was done using Time-Domain Reflectometer (TDR) method. Each germplasm accession was sown in four-row planes with a length of $2 \mathrm{~m}$ with $20 \mathrm{~cm}$ distance between lines.

\subsection{Measurements of physiological traits of flag leaf}

Data were recording from ten plants randomly, during 10 days after heading for two years in both treatments $(\mathrm{N}$ and $\mathrm{D})$.

\section{3. $R W C$ quantification}

In order to measure the RWC in flag leaves, weighting method was used (Teulat et al., 2003). RWC was calculated using the formula (Liu et al., 2015):

$\mathrm{RWC}=(\mathrm{fw}-\mathrm{dw}) /(\mathrm{tw}-\mathrm{dw}) \times 100 \%$

where $\mathrm{fw}$ is fresh leaves weighted, $\mathrm{dw}$ is dried leaves weighted, and tw is turgid leaves weighted.

\subsection{SPD quantification}

The content of relative chlorophyll of flag leaf (CFL) was measured using SPAD-502 chlorophyll photometer from top, medium, and bottom part of flag leaf (Liu et al., 2015). The averaged SPD values from replications were used for the analysis. 


\subsection{PSII quantification}

Chlorophyll fluorescence signal was measured after adapted leaves in darkness for at least 20min (FMS2, Hansatech, King's Lynn, Norfolk, UK). The maximum potential quantum efficiency of PSII photochemistry was calculated as (Genty et al., 1989; Krause and Weis, 1991):

\section{Fv/Fm,}

where $\mathrm{Fv}=\mathrm{F} 0-\mathrm{Fm}$

F0 is the initial chlorophyll fluorescence yield and Fm is the maximum chlorophyll fluorescence yield in a light adapted leaf.

\subsection{Measurements of morphological traits of flag leaf}

FLL is from the base of ligula to tip of the leaf, in $\mathrm{cm}$ and FLW, is the widest part of the leaf, in $\mathrm{cm}$.

\subsection{Phenotypic data analysis}

Variance components were estimated using GenStat $_{15}$. Heritabilities and correlations of all traits were calculated using $\mathrm{SAS}_{9.0}$ software and $\mathrm{SPSS}_{24}$, respectively. Best Linear Unbiased Estimates (BLUEs) of phenotypic data based on $\mathrm{G} \times \mathrm{E}$ variance were used in association analysis (Haseneyer et al., 2010).

\subsection{Genotypic and population structure analysis}

The whole panel was genotyped (Kraakman et al., 2004, 2006) using 14 AFLP primer combinations and 11 SSRs. Twenty-one SSRs were added again to this population by Aghnoum et al. (2010). Markers with Minor Allele Frequency (MAF) fewer than 5\% and more than $10 \%$ missing data were eliminated. Polymorphism information content (PIC) value was calculated using Powermarker ${ }_{3.25}$ (Chen et al., 2011).

Population structure was estimated using Structure ${ }_{2.3}$ based on Bayesian clustering model (Pritchard et al., 2010). The $\mathrm{K}$ number (sub-populations) was set from 2 to 20 using admixture model, with a burn-in of 100,000 iterations and 100,000 Markov Chain Monte Carlo (MCMC) iterations.

After selecting the value of $\mathrm{K}$ based on $\operatorname{LnP}(\mathrm{D})$, again 10 runs were made for the selected $K$. The $\Delta K$ index was calculated as:

$\Delta \mathrm{K}=[\mathrm{L}, '(\mathrm{~K})] / \mathrm{Stdev}$

where

$\mathrm{L}^{\prime},(\mathrm{K})=\mathrm{L}^{\prime}(\mathrm{K}) \mathrm{n}-\mathrm{L}^{\prime}(\mathrm{K}) \mathrm{n}-1$,

$\mathrm{L}^{\prime}(\mathrm{K})=\mathrm{L}(\mathrm{K}) \mathrm{n}-\mathrm{L}(\mathrm{K}) \mathrm{n}-1$,

and $L(K)=$ An average of 20 values of $L n P(D)$

The best $\mathrm{K}$ was determined where the graph of $\Delta \mathrm{K}$ peaked in the range of sub-populations. The Q-Matrix was extracted based on the $\mathrm{K}$ value (Kraakman et al., 2004; Ahmad et al., 2014). The NJ dendrogram also was constructed to determine the sub-populations graphically using Tassel $_{5}$ (Mariey et al., 2013; Nei and $\mathrm{Li}, 1979)$.

\subsection{LD and association analysis}

LD was estimated by calculating squared correlation coefficient between the pairs of loci $\left(\mathrm{r}^{2}\right)$ using Tassel $\mathrm{H}_{5}$ (Bradbury et al., 2007; Arnott et al., 2014). Significant LD was considered at $\mathrm{P}<0.01$. The average of $\mathrm{r}^{2}$ values in different genetic distances was calculated to determine the LD pattern in the panel. Markers with $M A F \geq 0.05$ were used for LD calculation (Mueller, 2004).

Association analysis based on K-Q matrix was performed using mixed linear model (MLM) on Tassel $_{3}$ (Yu et al., 2005). To assess the significant marker trait associations, threshold $\mathrm{P}$-value was considered for all traits according to the approach proposed by Chan et al. (2010) and Pasam et al. (2012). The QTL locations were drawn on the map using MapChart ${ }_{2.3}$ software.

\section{Results and Discussion}

\subsection{Phenotypic analysis}

The values of all traits in normal irrigation condition were higher than the values in drought stress. Over the normal irrigation treatment, FLW and RWC were moderately heritable (69\% and $62 \%$, respectively), whereas FLL and CFL showed low heritabilities (11\% and $22 \%$ ).

In drought stress condition FLL, FLW and CFL showed moderately heritable with values between 0.44 0.58, whereas PSII and RWC showed poorly heritabilities: 0.27 and 0.13 respectively. Variance analysis showed highly phenotypic variation in all traits. Genotypic variance and $\mathrm{G} \times \mathrm{Y}$ and $\mathrm{G} \times \mathrm{E}$ and $\mathrm{G} \times \mathrm{Y} \times \mathrm{E}$ interactions were significant $(\mathrm{P}<0.01)$ for all traits.

The results of correlation coefficients between all traits are shown in Table 1. FLL is found to be highly correlated with FLW in both $\mathrm{N}$ and D conditions, but it showed weak correlation with PSII and RWC in drought stress. In both treatments, there was a significant positive correlation between FLW and RWC. The traits (CFL and PSII) were significantly correlated in both experimental conditions. The results showed no significant correlation between CFL and FLL and FLW (Table 1). It means chlorophyll content in the flag leaves was not associated with FLL and/or width. 
Table 1. Correlation coefficients among flag leaf traits based on data from each treatment per two years

\begin{tabular}{lcllll}
\hline Trait & Treatment & FLW & CFL & PSII & RWC \\
\hline FLL & N & $0.698^{* *}$ & -0.066 & 0.036 & 0.004 \\
& D & $0.658^{* *}$ & -0.026 & $0.144^{*}$ & $0.124^{*}$ \\
FLW & N & & -0.095 & 0.082 & $0.185^{*}$ \\
& D & & -0.025 & 0.155 & $0.138^{*}$ \\
CFL & N & & & $0.103^{*}$ & -0.123 \\
& D & & & $0.205^{*}$ & -0.081 \\
PSII & N & & & 0.014 \\
& D & & & -0.112 \\
\hline
\end{tabular}

*,**: Significant at 0.05, 0.01 level, respectively. N: normal irrigation condition; D: drought stress condition; FLL: flag leaf length; FLW: flag leaf width; CFL: chlorophyll content of flag leaf; PSII: maximum efficiency of PSII in flag leaf; RWC: relative water content in flag leaf.

\subsection{Genetic diversity and population structure}

After excluding markers with MISS 10\% and MAF $5 \%$, in order to identify population structure, $\mathrm{LD}$, and association analysis, 218 polymorphic markers were used. The majority MAF of remaining markers ranged between 0.1-0.2 and 0.4-0.5. Marker efficiency in the panel showed the markers were distributed over all the seven chromosomes. The PIC value for most markers was higher than 0.25 and the average of polymorphic information content of all markers on each chromosome separately was from 0.27 on $7 \mathrm{H}$ to 0.40 on $6 \mathrm{H}$ (Figure $1)$.

To investigate the genetic relationships between cultivars, the Bayesian method was employed and the peak of likelihood was determined as the best number of sub-populations in the panel (Figure 2). Therefore, the highest value has been obtained at $\mathrm{K}=2$. The two subpopulations are defined as $\mathrm{K} 1$ and $\mathrm{K} 2$.

The number of genotypes assigned to $\mathrm{K} 1$ and $\mathrm{K} 2$ sub-populations was 83 and 67 , respectively. The variable proportional contribution of cultivars was observed into two sub-populations (Figure 3). Between $\mathrm{K} 1$ and K2 sub-populations, the Fst parameter was significant $(\mathrm{P}<0.05)$, which shows the prevalence of genetic structure. Neighbor-joining tree confirmed the population structure (Figure 4) and distinguished two groups of accessions corresponding to the structure results.

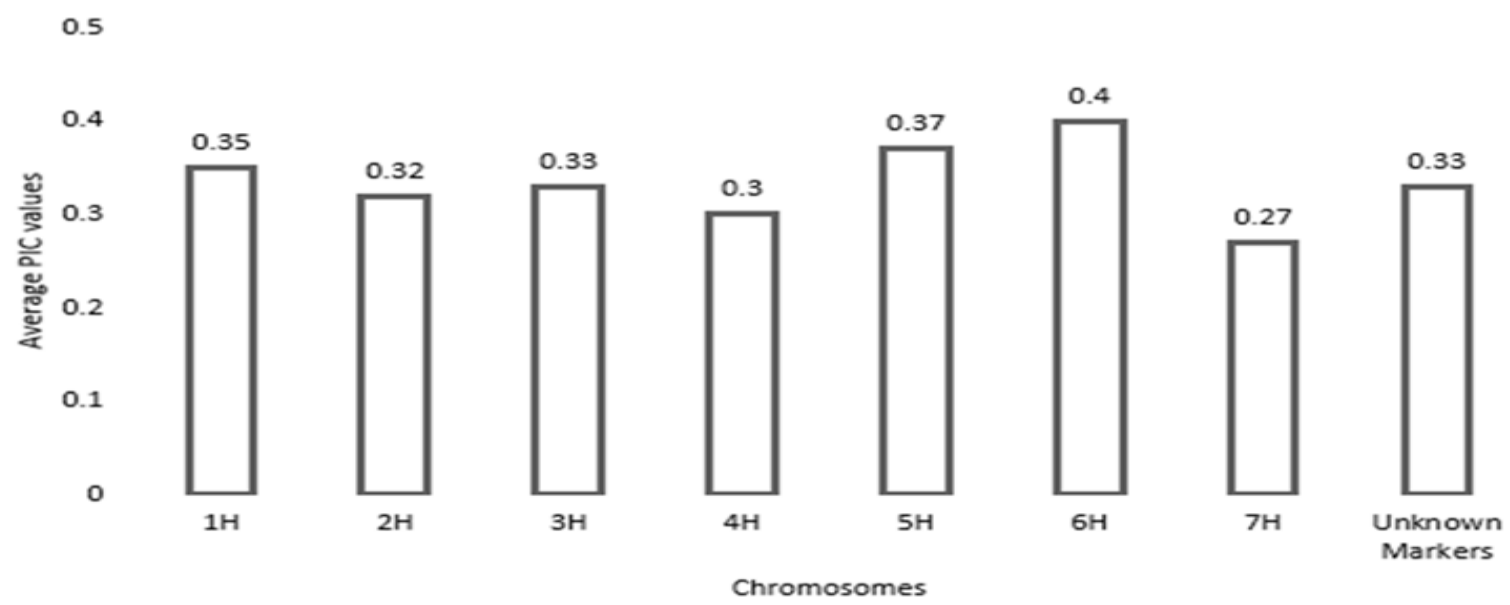

Figure 1. Average PIC values of the markers on each chromosomes.

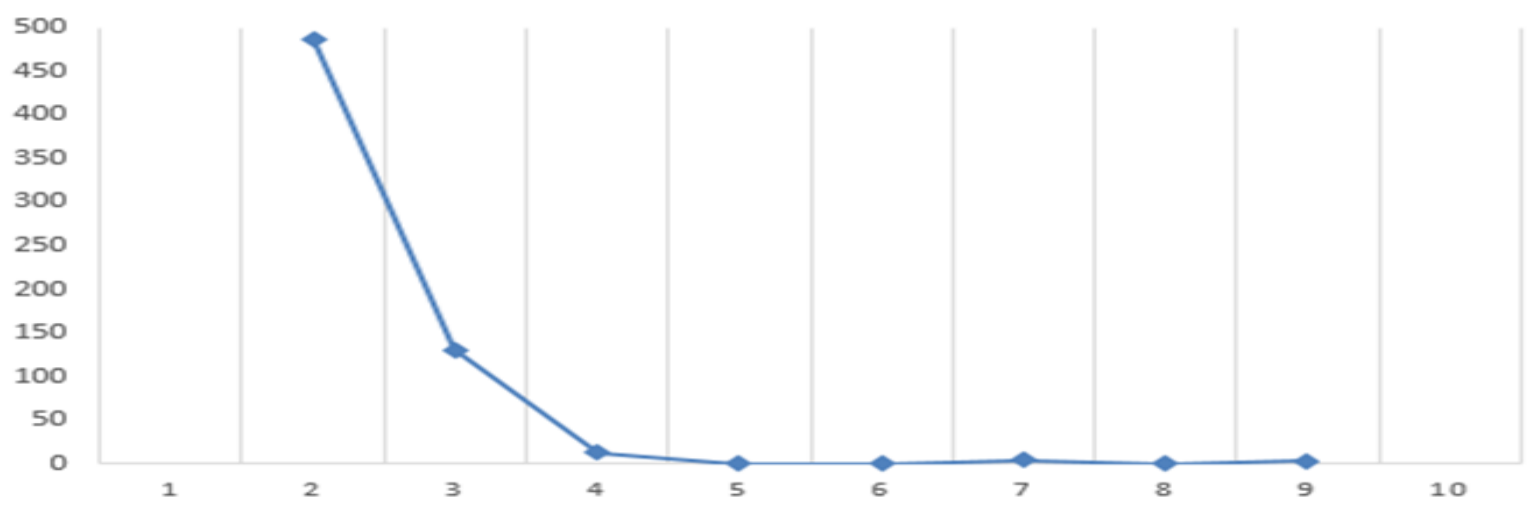

Figure 2. The likelihood to determine the best number of sub-populations in the range of 2 to $10 \mathrm{~K}$. 


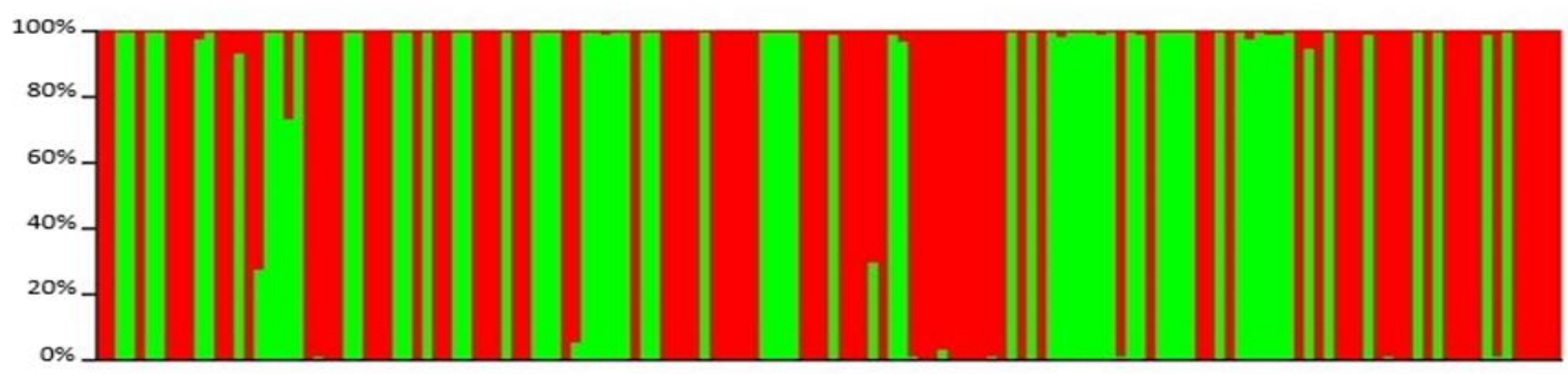

Figure 3. Population structure of 148 barley cultivars. Two color-coded sub-populations were distinct. The coloured portions reveal the proportional contribution of cultivars into two sub-populations.

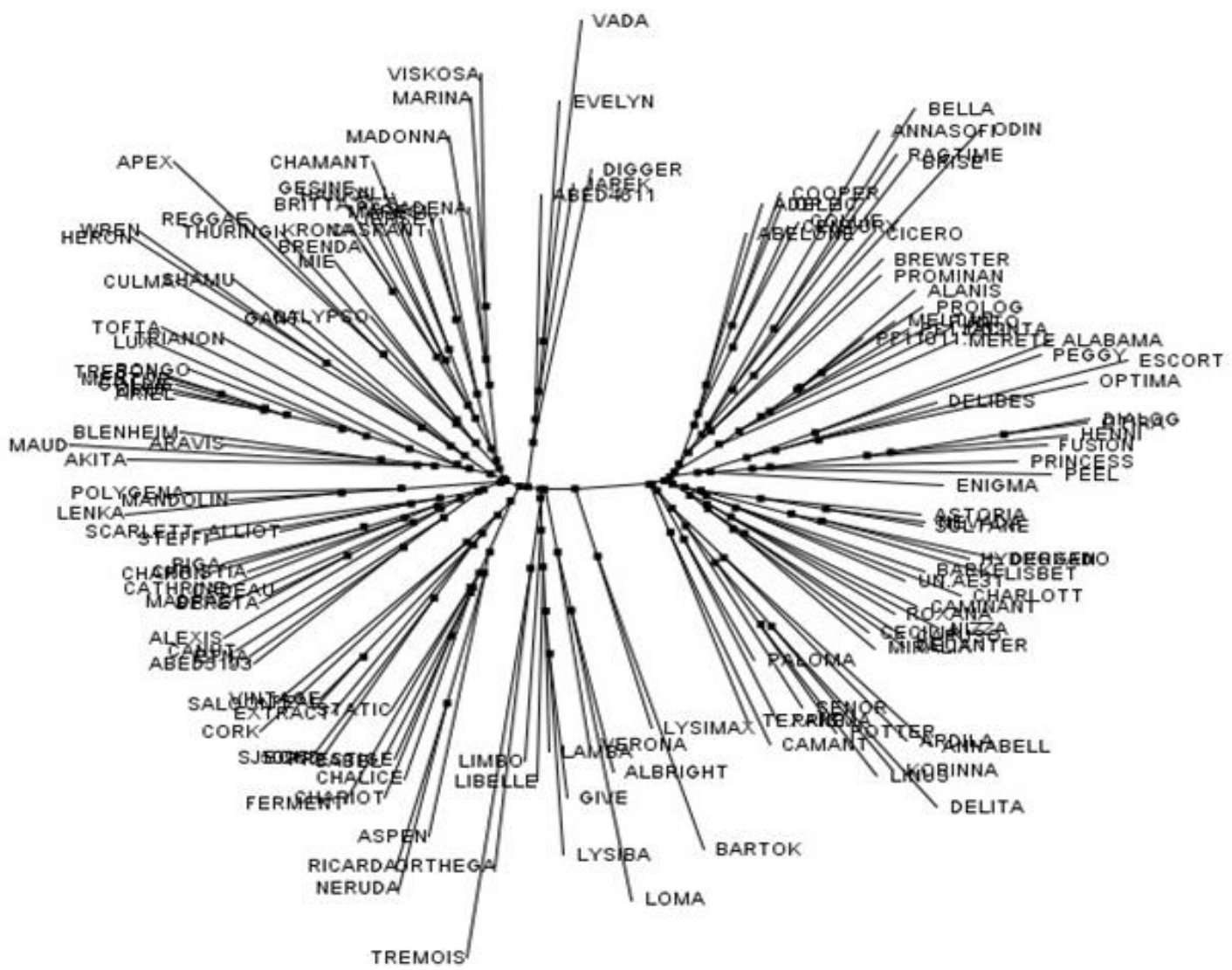

Figure 4. Unrooted neighbor-joining dendrogram showing genetic relationships between barley accessions, indicate the two groups in the panel.

\subsection{Linkage disequilibrium $(L D)$}

$\mathrm{LD}$ is the basis of QTL identification in AM analysis. The estimation of LD between all pairs of markers was performed in the panel. Significant LD values $(\mathrm{P}<0.01)$ between polymorphic sites with regions of high and low LD were observed. The pairs of loci were classified into five groups based on genetic distances: $<5 \mathrm{~cm}$ (tightly linked markers), $5-10 \mathrm{~cm}$ (linked markers), $\quad 10-20 \mathrm{~cm}$ (moderately linked markers), 20-50 cm (loosely linked markers) and $>50$ $\mathrm{cm}$ (rarely linked markers) (Maccaferri et al., 2011; Pasam et al., 2012). The scatter plot showed LD values decay with the genetic distance in the panel (Figure 5). The results show that among effective factors on LD such as population structure, genetic drift, migration, selection, and mutation, linkage is the most effective forces that caused disequilibrium in the population.

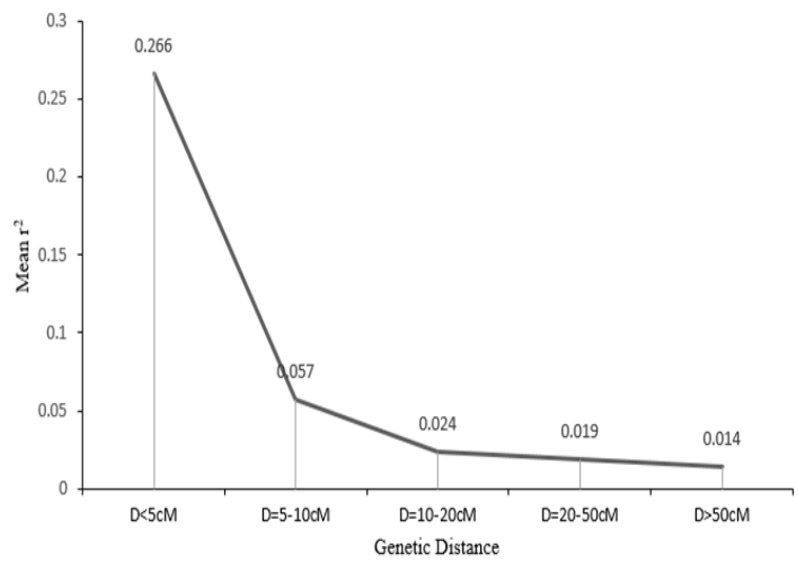

Figure 5. The relationship between mean of $\mathrm{LD}$ values with genetic distance of the pairs of loci. $\mathrm{D}<5 \mathrm{cM}$ : tightly linked markers, $\mathrm{D}=5-10 \mathrm{cM}$ : linked markers, $\mathrm{D}=10-20 \mathrm{cM}$ : moderately linked markers, $\mathrm{D}=20-50 \mathrm{cM}$ : loosely linked markers, $\mathrm{D}>50 \mathrm{cM}$ (rarely linked markers). 


\subsection{Marker-trait associations}

A total of thirty-seven significant QTLs were found for five physiological and morphological traits of flag leaf which spread on all chromosomes. Total phenotypic variance explained by all QTLs detected for each trait ranged from 18.2 to $52.5 \%$ for PSII and RWC, respectively (Table 2).
Trait PSII had the lowest phenotypic variance of a single QTL (3.3\%), while RWC showed the highest one $(9.5 \%)$ in drought (Table 2). CFL with 4 significant QTLs showed the lowest total phenotypic variation (18.3\%) and FLL with 13 detected QTLs showed the total phenotypic variance as $58.4 \%$ (Table 2).

Table 2. The results of marker/trait associations for Flag Leaf traits in spring barley population under drought stress.

\begin{tabular}{lcccccc}
\hline Trait & Treatment & N.QTL & Ch.N & Unknown QTL & $\mathbf{R}^{2}(\%)$ & $\mathbf{R}^{2}(\%)$ \\
\hline RWC & $\mathrm{N}^{*}$ & 5 & $2 \mathrm{H}, 7 \mathrm{H}$ & 5 & $3.5-9.8$ & 52.5 \\
& $\mathrm{D}$ & 1 & $5 \mathrm{H}$ & 6 & $3.8-9.5$ & 47.9 \\
CFL & $\mathrm{N}$ & 5 & $1 \mathrm{H}, 2 \mathrm{H}, 3 \mathrm{H}, 4 \mathrm{H}$ & 5 & $3.3-4.9$ & 40.6 \\
& $\mathrm{D}$ & 4 & $1 \mathrm{H}, 3 \mathrm{H}, 4 \mathrm{H}, 5 \mathrm{H}$ & - & $3.7-6.7$ & 18.3 \\
PSII & $\mathrm{N}$ & 4 & $2 \mathrm{H}, 5 \mathrm{H}$ & - & $3.6-6.0$ & 18.2 \\
& $\mathrm{D}$ & 1 & $5 \mathrm{H}$ & 9 & $3.3-6.0$ & 42.8 \\
FLL & $\mathrm{N}$ & 4 & $2 \mathrm{H}, 5 \mathrm{H}, 6 \mathrm{H}$ & 4 & $3.4-11.0$ & 40.7 \\
& $\mathrm{D}$ & 7 & $2 \mathrm{H}, 3 \mathrm{H}, 4 \mathrm{H}, 6 \mathrm{H}$ & 6 & $3.4-7.9$ & 58.4 \\
FLW & $\mathrm{N}$ & 4 & $2 \mathrm{H}, 3 \mathrm{H}, 5 \mathrm{H}, 7 \mathrm{H}$ & 6 & $3.3-7.5$ & 41.0 \\
& $\mathrm{D}$ & 2 & $4 \mathrm{H}, 5 \mathrm{H}$ & 6 & $3.7-5.4$ & 35.7 \\
\hline
\end{tabular}

$\mathrm{N}^{*}$ : normal irrigation condition; D: drought stress condition; N.QTL: number of significant QTLs; Ch.N: chromosome number; Unknown QTL: number of unknown significant markers; $\mathrm{R}^{2}$ : range of variance explained by $\mathrm{QTLs} ; \mathrm{R}_{\mathrm{T}}^{2}$ : total phenotypic variance explained by all QTLs.

\subsection{Relative water content $(R W C)$ :}

In normal irrigation condition, three putative QTLs were found on $2 \mathrm{H}$ for RWC trait which accounted for $12.6 \%$ phenotypic variation and two genomic regions on $7 \mathrm{H}$ with phenotypic variation as $8 \%$ (Table 2 and Figure $6)$. In drought, a significant region on $5 \mathrm{H}$ was detected with $4.2 \%$ phenotypic variation (Table 2 and Figure 6).

\subsection{Chlorophyll content of flag leaf (CFL):}

Two QTL regions were found on $2 \mathrm{H}$ which accounted for $6.7 \%$ phenotypic variation in normal irrigation condition. One of these at $122.406 \mathrm{~cm}$ was at the same control region for FLL in drought. On each chromosome of $1 \mathrm{H}, 3 \mathrm{H}$, and $4 \mathrm{H}$, two QTLs (one for ' $\mathrm{N}$ ' and one for ' $\mathrm{D}$ ' treatment) were detected for CFL trait but at different positions for each treatment. In drought stress, a genomic region on $5 \mathrm{H}$ at $44.900 \mathrm{~cm}$ was found to be significant on CFL (Figure 6).

\subsection{Maximum potential quantum efficiency of PSII:}

Four markers displayed significant associations with PSII in normal irrigation treatment, three of them were on $5 \mathrm{H}$ at different positions and together they explained $14.4 \%$ of the total observed phenotypic variation. The genomic region at $100.372 \mathrm{~cm}$ on $5 \mathrm{H}$ (marker 'E35M54-152') was found as the significant region on PSII in both ' $\mathrm{N}$ ' and ' $\mathrm{D}$ ' treatments (Figure 6). In drought, nine unknown markers were found to be significantly associated with PSII and they accounted for $38.7 \%$ phenotypic variation.

\subsection{Flag leaf length (FLL):}

Two putative QTL regions on $5 \mathrm{H}$ were detected for FLL trait in normal treatment, but at different positions (5.554 and $157.148 \mathrm{~cm}$ ). Chromosome $2 \mathrm{H}$ showed four significant regions associated with FLL, one region at $3.800 \mathrm{~cm}$ was significant in normal treatment and others were significantly exposed to drought. Marker 'HVM54-150' on $2 \mathrm{H}$ at $122.406 \mathrm{~cm}$ was detected as a significant associated marker which was repeated in two years and it accounted for $3.4 \%$ phenotypic variation in both years 2015 and 2016. Another repeated QTL for FLL was found in drought on $3 \mathrm{H}$ at $126.421 \mathrm{~cm}$ (marker 'E37M33-93') with the same proportion of phenotypic variation in two years (3.7\%). Chromosome $6 \mathrm{H}$ has two putative QTL regions on different positions for controlling FLL, one in ' $\mathrm{N}$ ' treatment with $3.5 \%$ phenotypic variation and the other in ' $\mathrm{D}$ ' with $4.2 \%$ phenotypic variation (Table 2 and Figure 6).

\subsection{Flag leaf width (FLW):}

Four QTLs underlying FLW were detected on $2 \mathrm{H}$, $3 \mathrm{H}, 5 \mathrm{H}$ and $7 \mathrm{H}$ in normal irrigation treatment with total phenotypic variation as $18.2 \%$. Six unknown markers were also found to be significant for this trait (Table 2 and Figure 6). In drought treatment, two putative QTLs were found on $4 \mathrm{H}$ and $5 \mathrm{H}$ at 125.075 and $12.543 \mathrm{~cm}$, respectively and they accounted for $10.6 \%$ phenotypic variation. Six unknown significant markers were found for FLW in drought stress too with $25.1 \%$ phenotypic variation. 
$1 \mathrm{H}$

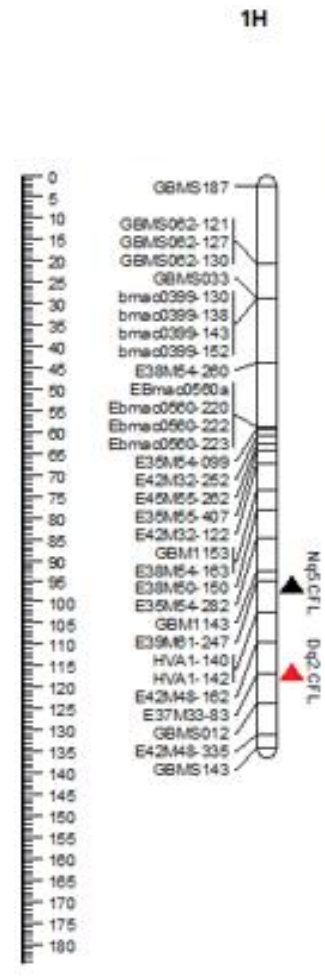

$2 \mathrm{H}$

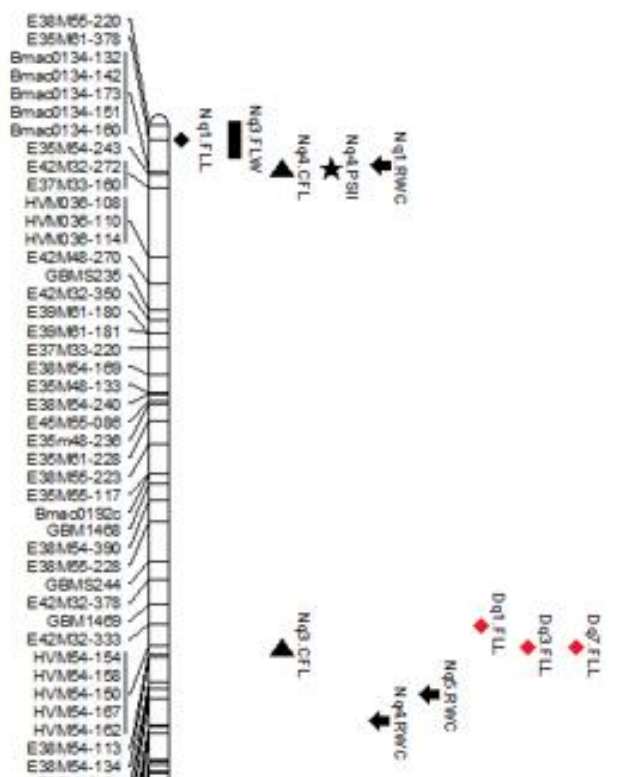

Зн

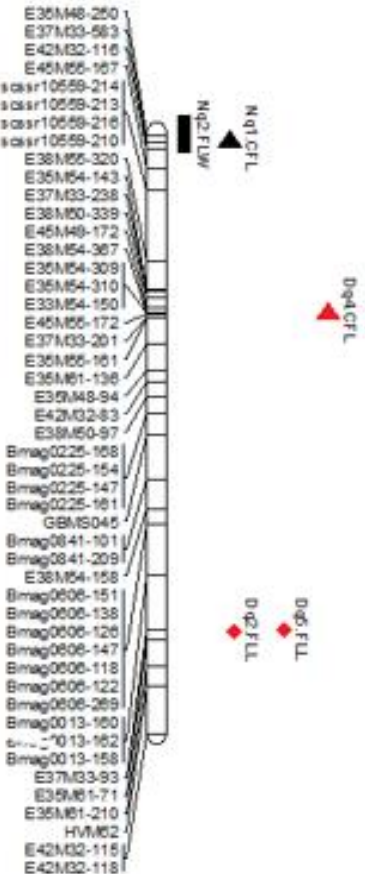

7H

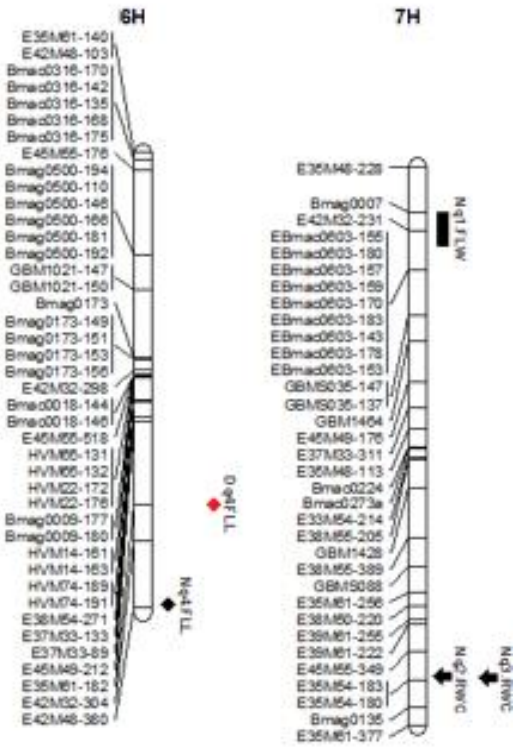

Emeno1 010

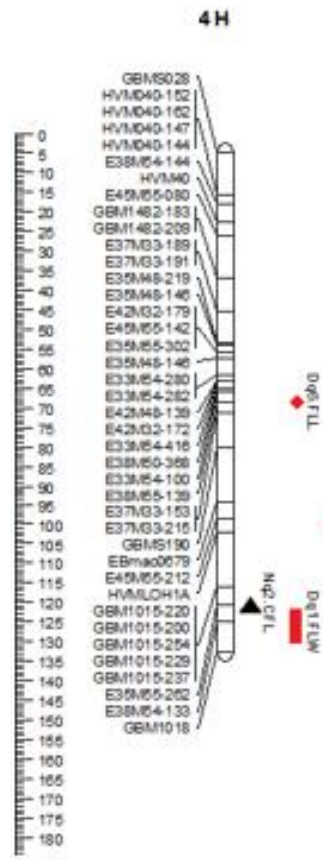

$5 \mathrm{H}$

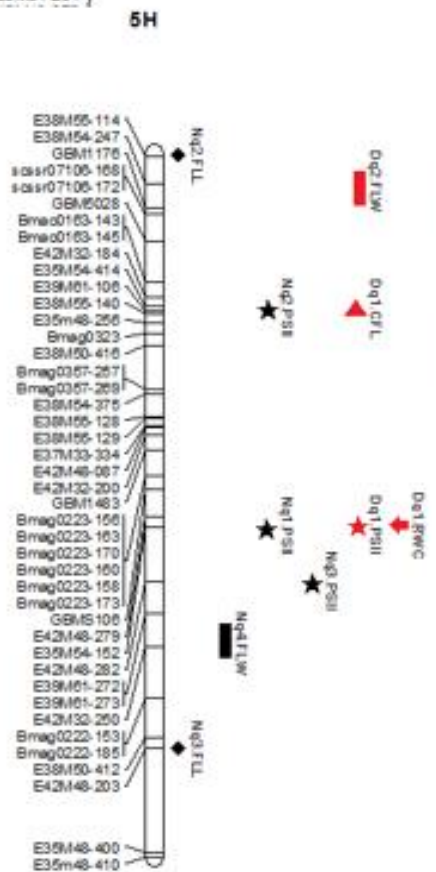

Figure 6. Chromosomes location of putative QTL associated with five physiological and morphological traits of flag leaf. Genetic distance scales in centiMorgans (cM) are placed at left margin. Location of QTL is indicated for normal irrigation treatment (black shapes) and drought stress treatment (red shapes).

AM is a strategy for detecting QTLs in which biparental crosses and screening generations of progeny are not necessary. Evaluation of associations between genotypes and phenotypes using AM based on statistical models approves the technique to any set of germplasm to detect QTLs for various traits (Roy et al., 2010). The role of flag leaf in growth and development of cereals is undeniable. QTL detection of flag leaf physiological and morphological traits during filling stage has not been analyzed based on GWAS in barley germplasm. The relationship between flag leaf physiological and morphological traits and detecting the genomic regions for these traits was analyzed in this study. FLL was found to be positively correlated with FLW, PSII, and RWC; and also PSII is strongly correlated with CFL in drought stress condition (Table 1), which showed that larger flag leaves providing more photosynthetic products are exposed to drought. Phenotypic statistics of 
all traits showed a continuous variation in water deficiency. The heritabilities of all traits in drought were higher than normal irrigation condition except CFL.

Since the effect of genotypexyear interactions was significant $(\mathrm{p}<0.01)$ for all traits, QTL detecting and association analysis were performed for each year separately, to detect either stable or specific associations across different environments. Eight and nine QTLs were found to be associated with the two flag leaf morphological traits (FLL and FLW) in two years in normal and drought treatments, respectively. These QTLs were located on chromosome $2 \mathrm{H}, 3 \mathrm{H}, 5 \mathrm{H}, 6 \mathrm{H}$, and $7 \mathrm{H}$ in normal condition and on chromosome $2 \mathrm{H}$, $3 \mathrm{H}, 4 \mathrm{H}, 5 \mathrm{H}$, and $6 \mathrm{H}$ in drought. Elberse et al. (2004) reported nine QTLs underlying leaf length and width on chromosome $1 \mathrm{H}, 2 \mathrm{H}, 4 \mathrm{H}, 5 \mathrm{H}$, and $6 \mathrm{H}$. Gyenis et al. (2007) detected three chromosome regions for FLL on $3 \mathrm{H}, 5 \mathrm{H}$, and $7 \mathrm{H}$ and three QTLs for FLW on $2 \mathrm{H}, 4 \mathrm{H}$, and $5 \mathrm{H}$ within a $\mathrm{BC} 2 \mathrm{~F} 8$ population from cultivated Harrington and wild accession OUH602. Xue et al. (2008) reported four QTLs controlling FLL and FLW on $5 \mathrm{H}$ and $7 \mathrm{H}$ in "Yerong $\times$ Franklin" population. Liu et al. (2015) detected seven QTLs on $2 \mathrm{H}, 3 \mathrm{H}$, and $7 \mathrm{H}$ for FLL and five QTLs on $2 \mathrm{H}$ and $4 \mathrm{H}$ for FLW. Shahraki and Fakheri (2016) reported three QTLs for FLL and FLW on $2 \mathrm{H}$ and $5 \mathrm{H}$ in normal condition in a 'Steptoe/Morex' doubled haploids population.

We detected two stable QTLs for FLL in drought treatment, on $2 \mathrm{H}$ at $122.406 \mathrm{cM}$ and on $3 \mathrm{H}$ at 126.421 $\mathrm{cM}$. These regions were close to the marker "HVM54150 " on $2 \mathrm{H}$ and marker "E37M33-93" on $3 \mathrm{H}$, showing that they have important role in flag leaf size in barley exposed to water deficiency. Two significant markers on $6 \mathrm{H}$ were detected to be associated with FLL, one in drought (E35M61-182) and the other in normal (E42M48-380) treatment but at different positions. Two putative regions on $4 \mathrm{H}$ with different positions were detected which controlled FLL and FLW exposed to drought. Since these traits were significantly correlated with each other (Table 1), a common putative QTL located on $2 \mathrm{H}$ at $3.800 \mathrm{cM}$ was found to control both FLL (Nq1.FLL) and FLW (Nq3.FLW) in normal condition (Figure 6). Two QTLs were found on $5 \mathrm{H}$ associated with FLW, 'Nq4.FLW' at $130.999 \mathrm{cM}$ and 'Dq2.FLW' at $12.543 \mathrm{cM}$, showing when a plant is exposed to water scarcity; genomic regions controlling traits were changed. QTL "Nq3.FLL" on 5H at 157.148 $\mathrm{cM}$ for FLL in normal condition was closed to 'QFLw5n' which was previously reported by Shahraki and Fakheri (2016) as a putative QTL for FLW in normal condition on $5 \mathrm{H}$ at $157.5 \mathrm{cM}$.

In order to sustain normal growth in drought condition, the plant increase water use efficiency (Liu et al., 2015; Arriagada et al., 2017). Plant water status affects photosynthesis process, plant growth, development, and yield (Arriagada et al., 2017). One of the important criteria has been widely used to explain plant water status in barley is flag leaf RWC (Liu et al., 2015; Forster et al., 2004). Flag leaf RWC is an important biochemical index revealing the stress intensity (Alizade, 2002). Several QTLs for RWC were reported in previous studies on chromosomes $2 \mathrm{~h}, 4 \mathrm{~h}, 5 \mathrm{~h}$, $6 \mathrm{~h}$, and $7 \mathrm{~h}$ in different water regimes (Fan et al., 2015; Liu et al., 2015). In this study, three QTLs were found for RWC on $2 \mathrm{H}$ at $10.876,134.720$, and $140.642 \mathrm{M}$ in normal irrigation condition (Figure 6). These QTLs were closed to 'Bmac0134-142', 'E33M54-230', and 'E37M33-501' markers, respectively.

Diab et al. (2004) also detected QTL "QOp.TaEr$2 \mathrm{H} .1$ " on the chromosome $2 \mathrm{H}$ closed to marker 'Bmac0134' (7.2 to $12.2 \mathrm{cM}$ ) for leaf water potential in a population of $167 \mathrm{~F} 8$ recombinant inbred lines. In normal treatment, a putative genomic region on $7 \mathrm{H}$ at $140.172 \mathrm{cM}$ was detected as significant QTL for RWC, while a QTL on chromosome arm 7HL for RWC under drought conditions has been reported previously (Diab et al., 2004). Shahraki and Fakheri (2016) reported two QTLs 'QRwc6s' and 'QRwc7s' on 6H and 7H under the salinity stress conditions for RWC. In drought stress treatment, one QTL were found on $5 \mathrm{H}$ at $100.372 \mathrm{cM}$ which has significant effect on RWC and PSII.

Abundant nutrition production is necessary in order to sustain crop growth and this depends on the CFL (Liu et al., 2015; Yap and Harvey, 1972). The positive correlation between leaf chlorophyll content and photosynthetic capacity was reported previously (Xue et al., 2008; Teng et al., 2004; Araus et al., 1997). Detecting QTLs for CFL was rarely performed previously in barley by GWAS. This et al. (2000) reported more than 10 QTLs on $2 \mathrm{H}, 4 \mathrm{H}, 5 \mathrm{H}, 6 \mathrm{H}$, and $7 \mathrm{H}$ in a recombinant inbred line population for chlorophyll content at early growth stage of barley. Guo et al. (2008) reported five associated genomic regions on chromosomes $2 \mathrm{H}$ and $4 \mathrm{H}$ for CFL at post-flowering stage in 194 RIL lines. In this study, CFL was evaluated as a drought tolerance criterion. Nine putative QTLs were found on $1 \mathrm{H}, 2 \mathrm{H}, 3 \mathrm{H}, 4 \mathrm{H}$, and $5 \mathrm{H}$ under two water treatments and no similar genomic region was previously reported, showing that novel QTLs were detected in this study for CFL exposed to drought.

In normal irrigation condition, two QTLs were mapped on $2 \mathrm{H}$ at 122.406 and $10.867 \mathrm{cM}$ near 'HVM54-158' and 'Bmac0134-173' markers, respectively. The QTL 'Nq4.CFL' on $2 \mathrm{H}$ at $10.867 \mathrm{M}$ was also found as significant putative QTL 'Nq4.PSII' for the trait PSII in normal treatment, showing this genomic region has an important role in the development of chloroplast and photosynthesis at grain filling stage in barley. Previous studies reported several QTLs on $2 \mathrm{H}$ for CFL in DH populations (Xue et al., 
2008; Liu et al., 2015). Three putative QTLs were detected at $1 \mathrm{H}, 3 \mathrm{H}$, and $4 \mathrm{H}$ in normal treatment, while three QTLs were also detected on the same chromosomes in drought treatment but at different positions showing that the genetic control of the expression of the trait CFL differed under water scarcity.

Previous studies showed that Fv/Fm ratio was used as the most common parameter for the evaluation of drought stress. Fv/Fm ratio determines the maximum quantum efficiency of PSII exposed to water stress conditions (Gregoriou et al., 2007; Melgar et al., 2009; Khaleghi et al., 2012). Khaleghi et al. (2012) showed that when a plant received less water, the Fv/Fm ratio is reduced. Faraloni et al. (2011) reported $90 \%$ reduction of the Fv/Fm ratio in olive cultivars exposed to drought. In this study, a QTL for PSII was detected on chromosome $5 \mathrm{H}$ at $100.372 \mathrm{cM}$ which is repeated in both treatments, showing that this genomic region is related to the drought tolerance of photosynthesis in barley. In addition, two more QTLs for PSII were found on the same chromosome at 44.900 and $114.402 \mathrm{cM}$ in normal irrigation condition. In the study of WójcikJagła et al. (2013), two QTLs (QPSII.sthb-4H and QPSII.sthb-5H) were detected in the malting barley population in drought stress. In normal treatment, another QTL on $2 \mathrm{H}$ was identified which was common with the trait CFL. Guo et al. (2008) reported two QTLS for $\mathrm{fv} / \mathrm{fm}$ ratio on chromosome $2 \mathrm{H}$ at 116.0 and 135.7 cM. Mora et al. (2016) identified two QTLs for quantum yield of PSII on chromosome $4 \mathrm{H}$ under rainfed condition in 137 recombinant chromosome substitution lines (RCSL) of barley.

\section{Conclusions}

In this study, several derived QTLs were colocalized or showed overlapping with each other. QTLs for traits FLL, FLW, CFL, PSII, and RWC in normal treatment are semi overlapped on chromosome $2 \mathrm{H}$. Traits FLL and CFL in drought and normal treatment, respectively were co-localized at the same region on $2 \mathrm{H}$. On chromosome $3 \mathrm{H}$, traits FLW and CFL were approximately overlapped with each other in normal treatment.

The approximately overlapping between genomic regions controlling traits were observed on $5 \mathrm{H}$ for traits RWC and PSII in drought, FLW and FLL in drought and normal, respectively and also CFL in drought and PSII in normal treatment. The results suggest that major loci located on chromosomes $2 \mathrm{H}, 3 \mathrm{H}, 4 \mathrm{H}$, and $5 \mathrm{H}$ are involved in the development of flag leaf characteristics in drought stress. As expected, the most QTLs identified in this study were novel, because of population structure and GWAS procedure.
In conclusion, evaluation of non-relative cultivars using association genetics approaches can attentively reveal the genomic structure of traits related to the activity of the photosynthetic apparatus under drought stress condition at grain filling stage. Therefore, chlorophyll fluorescence parameters were performed as selection criteria for drought tolerance. Moreover, this study provides useful information for marker-assisted selection of barley and potential use in breeding programs in areas where drought is a significant constraint. Since several genomic regions detected for traits in this study were unknown, there is need to saturate the genetic map with additional types of markers to combine and overlap the current results with previously detected QTLs. This will lead to the detection of supplemental associations and improve the significance of existing QTLs during water deficiency and would be useful in future marker-assisted barley breeding programs.

\section{Acknowledgements}

The authors thank all collaborating partners of the Sistan Agricultural and Natural Resources Research and Education Centre for their support in performing the field trials.

\section{Bibliographic References}

Aghnoum, R., Marcel, T.C., Johrde, A., Pecchioni, N., Schweizer, P., Niks, R.E., 2010. Basal host resistance of barley to powdery mildew: connecting quantitative trait loci and candidate genes. Molecular Plant-Microbe Interactions, 23, 91-102.

Agrama, H.A., Eizenga, G.C., Yan, W., 2007. Association mapping of yield and its components in rice cultivars. Molecular Breed, 19, 341-356.

Ahmad, M.A, Khan, S.H, Khan, A.S, Kazi, A.M, Basra, S.M.A., 2014. Identification of QTLs for drought tolerance traits on wheat chromosome $2 \mathrm{~A}$ using association mapping. International Journal of Agricultural Biology, 16, 862-870.

Alizade, A., 2002. Soil, Water and Plants Relationship, third ed. Emam Reza University Press, Mashhad, Iran, ISBN, 9646582-21-4.

Araus, J.I., Bort, J., Ceccarelli, S., Grando, S., 1997. Relationship between leaf structure and carbon isotope discrimination in field grown barley. Plant Physiology and Biochemistry, 35(7), 533-541.

Arnott, A., Wapling, J., Mueller, I., Ramsland, P.A., Siba, PM., Reeder, J.C., Barry, A.E., 2014. Distinct patterns of diversity, population structure and evolution in the AMA1 genes of sympatric Plasmodium falciparum and Plasmodium vivax populations of Papua New Guinea from an area of similarly high transmission. Malaria Journal, 13, 233. 
Arriagada, O., Mora, F., Quitral, Y., Del Pozo, A., 2017. Identification of QTL underlying agronomic, morphological and physiological traits in barley under rainfed conditions using SNP markers. Acta Scientiarum. Agronomy Maringá, 39(3), 321-329.

Berdahl, J.D., Rasmusson, D.C., Moss, D.N., 1972. Effects of leaf area on photosynthetic rate, light penetration, and grain yield in barley. Crop Science, 12, 177-80.

Bimpong, I.K., Serraj, R., Chin, J.H., Ramos, J., Mendoza, E.M.T., Hernandez, J.E., Mendioro, M.S., Brar, D.S., 2011. Identification of QTLs for Drought-Related Traits in Alien Introgression Lines derived from Crosses of Rice (Oryza sativa cv. IR64) $\times$ O. glaberrima under Lowland Moisture Stress. Journal of Plant Biology, 54, 237-250.

Brachi, B., Meyer, C.G., Villoutreix, R., Platt, A., Morton, T.C., Roux, F., Bergelson, J., 2015. Coselected genes determine adaptive variation in herbivore resistance throughout the native range of Arabidopsis thaliana. Proceedings of the National Academy of Sciences USA, 112, 4032-4037.

Bradbury, P.J., Zhang, Z., Kroon, D.E., Casstevens, T.M., Ramdoss, Y., Buckler, E.S., 2007. TASSEL: software for association mapping of complex traits in diverse samples. Bioinformatics, 23, 2633-2635.

Breseghello, F., Sorrells, M.E., 2006. Association mapping of kernel size and milling quality in wheat (Triticum aestivum L.) cultivars. Genetics, 172, 1165-1177.

Chan, E.K., Rowe, H.C., Kliebenstein, D.J., 2010. Understanding the evolution of defense metabolites in Arabidopsis thaliana using genome-wide association mapping. Genetics, 185(3), 991-1007.

Chen, C.X., Li, S.C., Wang, S.Q., Liu, H.N., Deng, Q.M., Zheng, A.P., et al., 2011. Assessment of the Genetic Diversity and Genetic Structure of Rice Core Parent Guichao 2, its Parents and Derivatives. Journal of Plant Science, 6, 66-76.

Comadran, J., Russell, J.R., Booth, A., Pswarayi, A., Ceccarelli, S., Grando, S., Stanca, A.M., Pecchioni, N., Akar, T., et al., 2011. Mixed-model association scans of multienvironmental trial data reveal major loci controlling yield and yield related traits in Hordeum vulgare in Mediterranean environments. Theoretical and Applied Genetics, 122, 13631373.

Comadran, J., Thomas, W.T.B., van Eeuwijk, F.A., Ceccarelli, S., Grando, S., Stanca, A.M., et al., 2009. Patterns of genetic diversity and linkage disequilibrium in a highly structured Hordeum vulgare association mapping population for the Mediterranean basin. Theoretical and Applied Genetics, 119, 175-187.

Diab, A.A., Teulat-Merah, B., This, D., Ozturk, N.Z., Benscher, D., Sorrells, M.E., 2004. Identification of droughtinducible genes and differentially expressed sequence tags in barley. Theoretical and Applied Genetics, 109, 1417-1425.

Elberse, I.A.M., Vanhala, T.K., Turin, J.H.B., Stam, P., van Damme, J.M.M., van Tienderen, P.H., 2004. Quantitative trait loci affecting growth-related traits in wild barley (Hordeum spontaneum) grown under different levels of nutrient supply. Heredity, 93, 22-33.
Fan, Y., Shabala, S., Ma, Y., Xu, R., Zhou, M., 2015. Using QTL mapping to investigate the relationships between abiotic stress tolerance (drought and salinity) and agronomic and physiological traits. BMC Genomics, 16(1).

Faraloni, C., Cutino, I., Petruccelli, R., Leva, A.R., Lazzeri, S., Torzillo, G., 2011. Chlorophyll fluorescence technique as a rapid tool for in vitro screening of olive cultivars (Olea europaea L.) tolerant to drought stress. Environmental and Experimental Botany, 73, 49-56.

Forster, B.P., Ellis, R.P., Moir, J., Talame, V., Sanguineti, M.C., Tuberosa, R., et al., 2004. Genotype and phenotype associations with drought tolerance in barley tested in North Africa. Annual Apply Biology, 144, 157-68.

Genty, B., Briantais, J., Baker, N., 1989. The relationship between the quantum yield of photosynthetic electron transport and quenching of chlorophyll fluorescence. Biochimica et Biophysica Acta, 990, 87-92.

González, A., Martín, I., Ayerbe, L., 2008. Yield and osmotic adjustment capacity of barley under terminal water-stress conditions. Journal of Agronomy Crop Science, 194, 81-91.

Gregoriou, K., Pontikis, K., Vemmos, S., 2007. Effects of reduced irradiance on leaf morphology, photosynthetic capacity, and fruit yield in olive (Olea europaea L.). Photosynthetica, 45(2), 172-181.

Guo, P., Baum, M., Varshney, R., Graner, A., Grando, S., Ceccarelli, S., 2008. QTLs for chlorophyll and chlorophyll fluorescence parameters in barley under post-flowering drought. Euphytica, 163(2), 203-214.

Gyenis, L., Yun, S.J., Smith, K.P., Steffenson, B.J., Bossolini, E., Sanguineti, M.C., et al., 2007. Genetic architecture of quantitative trait loci associated with morphological and agronomic trait differences in a wild by cultivated barley cross. Genome, 50, 714-23.

Hasan, M., Friedt, W., Pons-Kuhnemann, J., Freitag, N.M., Link, K., Snowdon, R.J., 2008. Association of gene-linked SSR markers to seed glucosinolate content in oilseed rape (Brassica napus ssp napus). Theoretical and Applied Genetics, $116,1035-1049$.

Haseneyer, G., Stracke, S., Paul, C., Einfeldt, C., Broda, A., Piepho, H.P., Graner, A., Geiger, H.H., 2010. Population structure and phenotypic variation of a spring barley world collection set up for association studies. Plant Breeding, 129(3), 271-279.

Horsley, R.D., Franckowiak, J.D., Schwarz, P.B., 2009. Barley, in: Carena MJ, editor. Cereals. US: Springer, p. 22750.

Igartua, E., Casas, A.M., Ciudad, F., Montoya, J.L., Romagosa, I., 1999. RFLP markers associated with major genes controlling heading date evaluated in a barley germ plasm pool. Heredity, 83, 551-559.

Jannink, J.L., Walsh, B., 2002. Association mapping in plant populations, in: Kang M.S. (Ed.), Quantitative Genetics, Genomics and Plant Breeding. CABI Publishing Oxon UK, p. 59-68. 
Kerwin, R., Feusier, J., Corwin, J., Rubin, M., Lin, C., Muok, A., et al., 2015. Natural genetic variation in Arabidopsis thaliana defence metabolism genes modulates field fitness. eLife, 4, e05604.

Khaleghi, E., Arzani, K., Moallemi, N., Barzegar, M., 2012. Evaluation of Chlorophyll Content and Chlorophyll Fluorescence Parameters and Relationships between Chlorophyll a, b and Chlorophyll Content Index under Water Stress in Olea europaea cv. Dezful. World Academy of Science, Engineering and Technology, 68.

Kraakman, A.T.W., Martı'nez, F., Mussiraliev, B., van Eeuwijk, F.A., Niks, R.E., 2006. Linkage disequilibrium mapping of morphological, resistance, and other agronomically relevant traits in modern spring barley cultivars. Molecular Breeding, 17, 41-58.

Kraakman, A.T.W., Niks, R.E., van den Berg, P.M.M.M., Stam, P., Van Eeuwijk, F.A., 2004. Linkage disequilibrium mapping of yield and yield stability in modern spring barley cultivars. Genetics, 168, 435-446.

Krause, G.H., Weis, E., 1991. Chlorophyll fluorescence and photosynthesis: the basics. Annual review of plant physiology and plant molecular biology, 42, 313-349.

Lakew, B., Henry, R.J., Ceccarelli S, Grando S, Eglinton J, Baum M., 2013. Genetic analysis and phenotypic associations for drought tolerance in Hordeum spontaneum introgression lines using SSR and SNP markers. Euphytica, 189, 9-29.

Liu, L., Sun, G., Ren, X., Li, C.H., Sun, D., 2015. Identification of QTL underlying physiological and morphological traits of flag leaf in barley. BMC Genetics, 16, 29.

Maccaferri, M., Sanguineti, M.C., Demontis, A., El-Ahmed, A., Garcia del Moral, L., Maalouf, F., et al., 2011. Association mapping in durum wheat grown across a broad range of water regimes. Journal of Experimental Botany, 62(2), 409-438.

Mariey, S.A., Mohamed, M.N., Khatab, I.A., El-Banna, A.N., Abdel Khalek, A.F., Al-Dinary, M.E., 2013. Genetic Diversity Analysis of Some Barley Genotypes for Salt Tolerance Using SSR Markers. Journal of Agricultural Science, 5(7).

Matin, M.A., Brown, J.H., Ferguson, H., 1989. Leaf water potential, relative water content, and diffusive resistance as screening techniques for drought resistance in barley. Agronomy Journal, 81, 100-5.

Melgar, J.C., Guidi, L., Remorini, D., Agati, G., Degli'innocenti, E., Castelli, S., et al., 2009. Antioxidant defences and oxidative-damage in salt-treated olive plants under contrasting sunlight irradiance. Tree Physiology, 29, 1187-1198.

Mir, R.R., Zaman-Allah, M., Sreenivasulu, N., Trethowan, R., Varshney, R.K., 2012. Integrated genomics, physiology and breeding approaches for improving drought tolerance in crops. Theoretical Applied Genetics, 125, 625-645.

Mora, F., Quitral, Y.A., Matus, I., Russell, J., Waugh, R., del Pozo, A., 2016. SNP-Based QTL Mapping of 15 Complex Traits in Barley under Rain-Fed and Well-Watered Conditions by a Mixed Modeling Approach. Front Plant Science, 7, 909.
Mueller, J.C., 2004. Linkage disequilibrium for different scales and applications. Briefings in Bioinformatics, 5, 355364.

Nei, M., Li, H., 1979. Mathematical model for studying genetic variation in terms restriction endonucleases. Proceedings of the National Academy of Sciences, 76, 5269. 5273.

Oraguzie, N.C., Wilcox, P.L., 2007. An overview of association mapping, in: Oraguzie NC, Rikkerink EHA, Gardiner SE (eds). Association mapping in plants. SpringerVerlag, New York, p. 1-10.

Pasam, R.K., Sharma, R., Malosetti, M., Eeuwijk, F.A.V., Haseneyer, G., Kilian, B., Graner, A., 2012. Genome-wide association studies for agronomical traits in a worldwide spring barley collection. BMC Plant Biology, 12, 16.

Pritchard, J.K., Wen, X., Falush, D., 2010. Documentation for structure software: 2.3. http://pritch.bsd.uchicago.edu/structure.html.

Roy, J.K., Smith, K.P., Muehlbauer, G.J., Chao, S., Close, T.J., Steffenson, B.J., 2010. Association mapping of spot blotch resistance in wild barley. Molecular Breeding, 26, 243256.

Shahraki, H., Fakheri, B.A., 2016. QTLs Mapping of MorphoPhysiological Traits of Flag Leaf in Steptoe $\times$ Morex Doubled Haploid Lines of Barley in Normal and Salinity Stress Conditions. International Journal of Farming and Allied Sciences, 5(5), 356-362.

Somers, D.J., Banks, T., Depauw, R., Fox, S., Clarke, J., Pozniak, C., McCartney, C., 2003. Genome wide linkage disequilibrium analysis in bread wheat and durum wheat. Genome, 50, 557-567.

Teng, S., Qian, Q., Zeng, D., Kunihiro, Y., Fujimoto, K., Huang, D., et al., 2004. QTL analysis of leaf photosynthetic rate and related physiological traits in rice (Oryza sativa $\mathrm{L}$ ). Euphytica, 135, 1-7.

Teulat, B., Zoumarou-Wallis, N., Rotter, B., Salem, M.B., Bahri, H., This, D., 2003. QTL for relative water content in field-grown barley and their stability across Mediterranean environments. Theoretical Applied Genetics, 108, 181-8.

This, D., Borries, C., Souyris, I., Teulat, B., 2000. QTL study of chlorophyll content as a genetic parameter of drought tolerance in barley. Barley Genetics Newsletter, 30, 20-23.

Thornsberry, J., Goodman, M., Doebley, J., Kresovich, S., Nielsen, D., 2001. Dwarf8 polymorphisms associate with variation in flowering time. Nature Genetics, 28, 286-289.

Tungland, L., Chapko, L.B., Wiersma, J.V., Rasmusson, D.C., 1987. Effect of erect leaf angle on grain yield in barley. Crop Science, 27(1), 37-40.

Wójcik-Jagła, M., Rapacz, M., Tyrka, M., Kościelniak, J., Crissy, K., Żmuda, K., 2013. Comparative QTL analysis of early short-time drought tolerance in Polish fodder and malting spring barleys. Theoretical Applied Genetics, 126, 3021-3034. 
Xue, D., Chen, M., Zhou, M., Chen, S., Mao, Y., Zhang, G., 2008. QTL analysis of flag leaf in barley (Hordeum vulgare L.) for morphological traits and chlorophyll content. Journal of Zhejiang University Science B, 9, 938-43.

Yap, T.C., Harvey, B.L., 1972. Relations between grain yield and photosynthetic parts above the flag leaf node in barley. Canadian Journal of Plant Science, 52, 241-246.

Yin, X., Kropff, M.J., Stam, P., 1999. The role of ecophysiological models in QTL analysis: the example of specific leaf area in barley. Heredity, 82, 415-421.
Yu, J., Pressoir, G., Briggs, W.H., Bi, I.V., Yamasaki, M., Doebley, J.F., et al., 2005. A unified mixed_model method for association mapping that accounts for multiple levels of relatedness. Nature Genetics, 38, 203-208.

Zhao, J., Sun, H., Dai, H., Zhang, G., Wu, F., 2010. Difference in response to drought stress among Tibet wild barley genotypes. Euphytica, 172, 395-403.

Zhu, C., Gore, M., Buckler, E.S., Yu, J., 2008. Status and prospects of association mapping in plants. Plant Genome, 1, 5-20. 